\title{
Fiqh Issues in Short Selling as Implemented in the Islamic Capital Market in Malaysia
}

\author{
Asyraf Wajdi Dusuki and Abdelazeem Abozaid \\ Department of Economics \\ Kulliyyah of Economics and Management Sciences \\ International Islamic University Malaysia, Malaysia \\ asyraf.w@iiu.edu.my, abozaid@iiu.edu.my
}

\begin{abstract}
Islamic capital market represents an assertion of Shariah principles in the capital market transactions where the market should be free from any elements or activities that are prohibited in Islam. The strict adherence to Shari'ah principles also implies that all financial instruments used by transacting parties in the capital market need to be Islamic. One of the most popular and commonly used financial instruments in conventional capital market is short selling. Many finance literature assert that short-selling provides liquidity, drives down overpriced stocks and generally increases efficiency of the markets. In general, the conventional short sale is selling a stock which investor does not actually own; a transaction which would clearly violate the general Islamic rule of 'do not sell what you do not own'. Nevertheless, the Shari'ah Advisory Council (SAC) of Malaysian Securities Commission has recently legalized the short selling instrument to be used in Islamic Capital Market in Malaysia. This paper, therefore aims to study fiqh issues surrounding the short selling instrument. Three main issues are specifically highlighted and discussed, namely the issue of bay'ma'dum (selling what the seller does not own), the eligibility of stock as object of a loan contract and benefiting from loan contract.
\end{abstract}

\section{Introduction}

Over the past three decades, Malaysia has been in the forefront of global initiatives and efforts to establish a viable, sustainable and feasible Islamic Capital Market that caters the needs of Muslims and also ensures that its products and services are attractive to all investors and issuers regardless of 
races or religions. Like its conventional counterpart, Islamic capital market plays an essential role in contributing to the country's economic growth and prosperity. Although Islamic capital market functions almost similarly as conventional capital market, its activities are carried out in ways which do not conflict with the principles of Shariah. In other words, Islamic capital market should be free from any involvement of activities prohibited by Islam and from elements like usury (riba), gambling (maysir) and excessive ambiguity (gharar). These prohibitions are mainly to promote justice and provide a level playing field in order to protect the interest and circumvent harms of all parties involved in market transactions, which is transpired in the objectives of Shari'ah (maqasid al-Shari 'ah).

In an attempt to further strengthen efficiency and enhance competitiveness of Malaysian capital market, the Securities Commission of Malaysia has recently legalized short-selling transaction, under a strict securities borrowing and lending (SBL) regulations. The Shariah Advisory Council (SAC) of Securities Commission at its $69^{\text {th }}$ meeting held on $18^{\text {th }}$ April 2006 resolved that regulated short-selling (RSS) is in compliance with Shariah as the inclusion of SBL principles in RSS eliminates the element of gharar.

This paper, therefore aims to review the resolution passed by the SAC of Securities Commission of Malaysia. In doing so, we shall also discuss some of the pertinent issues in Shari ah associated directly to short selling facility. The remaining paper is organized as follows: The following section starts by introducing the basic operation of short-selling as applied in conventional capital market. Some fiqhi issues pertaining to short-selling operation are further analysed in section three. The issues include eligibility of stocks to be a subject matter of a loan contract, issue of bay' ma'dum (selling what the seller does not own) and issue of benefiting from a loan contract. The conclusion is presented in the final section.

\section{What Is Short Selling?}

To understand the Shariah position on short selling would first require a sound knowledge about the practical operation of short selling. Thus, this section sheds lights on the concept of short selling and how it is actually implemented in capital market.

In conventional capital market, there is an instrument that allows investors to make money without actually owning any shares. This instrument is commonly known in equity market as short selling. In Malaysia, Bursa Malaysia (Stock Exchange of Malaysia) defines Regulated Short Selling (RSS) as: 
"the selling of approved securities where the seller does not, at the time of the execution of the sale, have an exercisable and unconditional right to vest such securities in the purchaser but has, prior to the execution of the sale, executed an agreement to borrow the approved securities as will enable delivery of the same to be made to the purchaser under the said sale, in accordance with the Rules relating to delivery and settlement". (Bursa Malaysia 2006) ${ }^{(1)}$.

In general, short selling is taken to denote sale of a security not owned by the investor at the point of transaction. The concept of short-selling involves borrowing stock that investors do not own, selling the borrowed stock and then buying and returning the stock when the price drops. In the actual market practice, the investor can arrange to have his broker borrow the stock from someone else, and then the borrowed stock is delivered to effect the sale. To cover his short position, the investor must subsequently purchase the stock and return it to the party that loaned the stock.

There are two main reasons why investors may want to opt for short selling, notably speculation and hedging (Fabozzi and Modigliani 2003). By speculation, investors normally assume that they will be able to make profits by speculating on an overpriced stock or market. Short-sellers anticipate that they will be able to buy the stock at a lower amount than the price at which they sold short. Thus, short sellers will make money if the stock actually goes down in price. The most famous example of this was when George Soros caused a great loss to the Bank of England in 1992, where he shorted $\$ 10$ billion worth of British pound for a one day gain in excess of $\$ 1$ billion $^{(2)}$.

On the other hand, for investors who use short selling to hedge, they are basically protecting other long positions with offsetting short positions. This is basically to mean that investors use short selling instrument to strategically reduce the investment risk of adverse price movements in an asset. In other words, investors hedge one investment by making another. This inevitably reduces their exposure to market price risks provided that the two securities invested are negatively correlated ${ }^{(3)}$.

(1) The Regulated Short Selling (RSS) based on the principle of securities borrowing and lending, was first introduced to the Malaysian capital market at the end of 1995. However, it was suspended at the end of 1997 following the economic crisis which threatened the stability of the share market activities in the Kuala Lumpur Stock Exchange (now Bursa Malaysia).

(2) George Soros is known as a hedge guru and his main expertise is in currency speculation. He is the principal investment advisor for the Quantum Fund, which is recognized for having the best performance record of any investment fund in the world over its 26-year history. Refer to Investopedia (2002).

(3) As opposed to speculation, where speculators make gueses on where they believe the market is headed, hedgers on the other hand reduce their risk by taking an opposite position in the market to what they are trying to hedge. The ideal situation in hedging would be to cause 
Despite criticisms that short selling traders manipulate stock prices in a mere speculative transaction, many exchanges have made it a legal activity for at least two good reasons: First, it provides the market with more and better information. Short sellers often complete extensive and legitimate due diligence to try and discover facts and flaws that support their speculation. That is one of the reasons why the work of short sellers is often regarded as being some of the most detailed and highest quality research in the market. Second, short selling provides liquidity, drives down overpriced securities and generally increases the efficiency of the markets. Because most short sellers are scrupulous and ethical, their actions are conducive to the health of the market.

As an illustration, let us look at an example of how short selling is actually operated in stock market. Suppose Ahmad anticipates that Al-Barakah Petroleum Limited common stock is overpriced at $\$ 20$ per share and wants to be in a position to benefit if his assessment is correct. Ahmad contacts his broker, Ali, indicating that he wants to sell 100 shares of Al-Barakah Petroleum Limited. Ali will do two things: (1) sell 100 shares of Al-Barakah Petroleum Limited on behalf of Ahmad and, (2) arrange to borrow 100 shares of AlBarakah from another party so that it could be delivered to the buyer. Suppose that Ali is able to sell the stock for $\$ 20$ per share and borrows the stock from Umar. The borrowed 100 shares will then be delivered to the buyer. The proceeds from the sale (ignoring commissions and other transaction costs) $)^{(4)}$ will be $\$ 2000$. However, the proceeds do not go to Ahmad because he has not given his broker (Ali) the 100 shares. Thus, Ahmad is said to be "short 100 shares".

If one week later the price of Al-Barakah Petroleum Limited stock decline to $\$ 15$ per share, Ahmad may instruct his broker (Ali) to buy 100 shares of AlBarakah. The cost of buying the shares (ignoring commissions and other transaction costs) is $\$ 1500$. The shares purchased are then delivered to Umar, who loaned 100 shares to Ahmad. At this point, Ahmad sold 100 shares and

4 one effect to cancel out another. For example, assume that a company specializes in producing cooking oil and it has a major contract due in six months, for which oil palm is one of the company's main inputs. The company is worried about the volatility of the oil palm market and believes that oil palm prices may increase substantially in the near future. In order to protect itself from this uncertainty, the company could buy a six-month futures contract in palm oil. This way, if palm oil experiences a $10 \%$ price increase, the futures contract will lock in a price that will offset this gain. Refer to Investopedia (2002).

(4) In actual market transaction, besides the commission paid to the broker, there will be two possible costs involved. First, a fee is charged by the lender of the stock. Second, for any dividend paid by the company while the stock is borrowed, short-seller (Ahmad) must compensate the actual owner of the stock for the dividends to which he was entitled. Refer to Fabozzi, et al. (2002). 
bought 100 shares, so he no longer has any obligation to his broker or to Umar, hence covering his short position. He is now entitled to the funds in his account that were generated by the trading activity. In this example, Ahmad sold the stock for $\$ 2000$ and bought it for $\$ 1500$. Thus, he realizes a profit before commissions of $\$ 500$.

\section{Fiqh Issues in Short Selling}

After highlighting the concept and mechanism of short-selling, we now turn our discussion to the various Shari ah issues pertaining to the transaction. Obviously, short selling involves two basic contracts: a sale contract, when the seller sells the stocks before owning them, and a loan contact, when the seller borrows stocks from the stocks owner (via broker) and sells them to the stocks buyer. The stock owner of course obtains some profit from it in the process.

To determine the legality of short selling, we need to find the answers to the following figh questions: Can stocks be a subject matter of loan contract? Can the seller sell the stocks before owning them? Finally, being a lender, can the stocks owner gain any financial benefit from lending his stocks? These questions will be answered in the following sections.

\section{Can Stocks be a Subject Matter of a Loan Contract?}

To answer the question whether stocks can be a subject matter of a loan contract requires instructive examination on the type of objects that are eligible for lending. Jurists have different views with regard to objects that may or may not be lent.

With the exception of Hanafi jurists, most jurists (the Malikis, Shafi is and Hanbalis) ruled that loans are permissible for all goods eligible for forward sale (salam). This means all properties that can be established as a liability on the borrower can be a subject matter of a loan contract. This includes fungible goods (mithli) and non-fungible goods (qimi). The former refers to properties which can be measured by weight, volume, length, or number of homogeneous units, while the latter is unique and differs in value significantly from other items of the same genus and kind (El-Gamal 2006).

Jurists of all different schools considered the forward sale of fungible commodities as one of the important conditions for it to be considered as a valid contract. This is because, if perished they can be replaced by an equal quantity of a similar property without any difference in the constituting units. The examples of homogeneous properties are gold, silver, money, rice, wheat, corn, barley, salt, oil, etc. Dissimilar or non-homogenous (qimi) properties are those 
the like of which could not be found in markets or even if it is found, dissimilarities would still exist. They include all those properties which cannot be exchanged by weight or measurement of capacity such as land, houses, animals, trees, precious stones, used cars or books, etc.

Accordingly, the majority of jurists are of the opinion that a loan contract can be validly concluded with regard to every property on which salam is valid. They argue that loan is valid with regard to animals as they can become the objects for a salam contract. This argument is based on the following Hadith: "It was narrated by Rafi that the Prophet (pbuh) borrowed a young camel, and then received a charity of camels and ordered Rafi to repay the man another young camel, Rafi said that the closest he could find was a six year old camel (which is more valuable). Then the Prophet (pbuh) ordered him to give it to the man, and added "the best among you is the one who is the best in repaying his debts $^{\prime(5)}$.

The above Hadith implies that the camel mentioned is clearly not measured by weight or volume. In this regard, any goods eligible for forward sale are controlled by description, and thus may be lent just like fungible goods (measurable by weight and volume). Thus, both fungibles and non-fungibles are eligible objects for lending ${ }^{(6)}$. More importantly these jurists render permissible loans of any items that can be established as a liability. This is because a loan requires repayment of an equivalent good. However, these jurists differed over the definition of equivalence. For example, Malikis define equivalence in terms of similarity of characteristics and amount, while Shafi is and Hanbalis define it in terms of its form. For example, they all agree that unique and expensive jewels may not be lent, since it is very likely that their equivalent cannot be found at the time of repayment ${ }^{(7)}$.

The Hanafies, on the other hand, argue that homogeneous (mithli) properties are the only proper object for the loan contract. They argue that a loan contract cannot validly be concluded with regard to non-homogeneous (qimi) properties at it is almost impossible to find an equivalent good to repay the loan ${ }^{(8)}$.

(5) Narrated by Muslim in his 'Sahih' 1224/3, Hadith No 1600; Abu Dawud in his 'Sunan' 274/3; Hadith No 3346; Tirmidhi in his Sunan 600/3, Hadith No 1318; Nasa'i in his Sunan 291/4, Hadith No 6210; Ibn Majah in his Sunan 767/2, Hadith No 2285.

(6) al-Dhakhirah by al-Qarafi: 287/5; Mughni al-Muhtaj by Sharbini: 119-118/2; al-Mughni by

Ibn Qudamah: 386-385/4; Hashiyat al-Dasuqi: 223-222/3.

(7) al-Zuhayli, al-Figh al-Islami wa Adillatuh, Dar al-Fikr, 1984, Vol. 5, p. 3790.

(8) Hashiyat Ibn 'Abidin:171/4. 
Based on the above, according to all jurists including the Hanfis, since stocks satisfy the homogeneous (mithli) properties, they are qualified to become the subject matter of a loan contract. However, it should not escape our noting that a part of what the stock originally represents is non-homogeneous properties (mal qimi), which breaches the Hanafis' conditions for the validity of lending stocks. On the other hand, non-homogeneous properties can be a subject matter in a loan contract. Nevertheless, such a loan then requires repayment of a equivalent good. This homogeneity means that the thing to be returned must be similar in terms of value or in shape by returning its like according to some jurists. Repayment of the similar stock in value is not applicable in short selling since the borrower settles the debt only when the value of the stock borrowed depreciates. Therefore, if taking the borrower to be returning the similar in value is not applicable to short selling, then we can rightly say that the similar in shape is what the borrower returns in short selling.

Another valid argument is to say that the stock is completely a homogeneous property, since it is used as a commercial paper regardless of what it represents, not as a thing to be borrowed for utilizing; therefore, the question of its coverage being homogeneous or non homogeneous should not be raised here. However, to give stocks the status of commercial papers this will have its legal consequences regarding selling and buying which will implicitly render stock as a non negotiable tool.

\section{Selling What the Seller Does Not Own}

One of the fundamental conditions that validate a selling contract is that the mahall al- 'aqd or ma'qud 'alayh (objects in trade) to be traded must exist and be owned by the seller at the time of contract. This is important because the purpose of a sale contract is to transfer ownership of the object of the sale to the buyer and ownership of the price to the seller. Otherwise the sale contract is deemed to be invalid sale (al-bay' al-fasid), also known as bay' ma'dum (selling object that does not exist) which has become a matter of contention amongst the scholars for so long. (al-Zuhayli 1984).

In essence, the short selling transaction is said to be in conflict with one Prophetic Hadith: "Do not sell what you do not possess"((9).

(9) The full version of the Hadith is as follows:

Ja'far ibn Abi Washiyah reported from Yusuf ibn Mahak, from Hakim ibn Hizam (who said): "I asked the Prophet: $O$ Messenger of God. A man comes to me and asks me to sell him what is not with me. I sell him (what he wants) and then buy the goods for him in the market (and deliver them). The Prophet replied: 'Do not sell what you do not possess'. This hadith is narrated by Abu Dawud in his Sunan, 3/768, hadith No 3503; Al-Tirmidhi in his Sunan, 4/228, hadith No 1232 ; Al- Nasa'i in his Sunan, 7/289, hadith No 4613. 
On the surface, the hadith implies that Ahmad (as in the case of our earlier example) cannot instruct his broker Ali to sell al-Barakah Petroleum Limited stocks, since neither Ahmad nor Ali owns the stocks. But can we conveniently conclude that the short selling is categorically prohibited solely based on this Hadith? Put it differently, is short selling prohibited on the basis of selling something before actually owning it or taking possession?

According to the Hanafis, Qabd is not an essential requirement (rukn) of sale but rather a subsidiary condition (shart al-nifadh). They clearly validate a bona fide sale by an unauthorized person (fuduli) who does not own the object but sell it nevertheless. In this case, the sale is deemed to be valid but not effective. It becomes effective only upon obtaining the owner's consent ${ }^{(10)}$. Thus qabd, is not a prerequisite of a valid contract and it is perfectly lawful to postpone it to a later date. Only in the case of the transaction of ribawi items (e.g. sale of gold with gold), is Qabd elevated to a prerequisite of a valid contract. Abu Hanifah exempted what is movable and transferable from what is immovable and non-transferable, for transfer of possession, according to him, is still possible by making the property available.

Malikis confined the Hadith on qabd to be applied only to food grains, which means that non-food grain items (e.g. cotton, palm oil etc.) may be sold prior taking possession (Imam Malik b. Anas 1989). Ibn Rushd confirmed this and stated, "There is no dispute in Maliki's school about the permissibility of selling thing, other than food, before taking possession and there is also no dispute in his school; about ribawi food (wheat, barley, dates and salt) that possession is a condition for its sale"(11). As for non-ribawi food, Maliki has two opinions: first, that it is disallowed (without prior possession). This is better known and is also the opinion of Ahmad and Abu Thawr, though these two authorities stipulated that food should be measured and weighed. Second, that it is permitted.

For Shafi is, possession is a condition for all kinds of property. Al-Shafi $\mathrm{i}$ deduces his opinion based on the Hadith of the Prophet s.a.w., "It is not permitted: to sell with a loan; to profit without corresponding liability (for loss); or to sell what you do not possess". On the Hadith of: "Do not sell anything until you receive it", Shafi'i's strictly adhere to the literal meaning of the Hadith to the extent that even the selling of immovable objects need to satisfy possession requirement prior to resale. However, his view is not shared

(10) al-Kasani, Bada'i $i$ al-Sana'i“, 5/148, al-Dardeer. al-Sharh al-Kabir, (Published with Hashiyat al-Dasuqi), 3/12, al-Shirazi. al-Muhadhdhab, 1/262-263; Ibn Qudamah, al-Mughni 6/295.

(11) Muhammad b. Ahmad Ibn Rushd al-Qurtubi, Bidayat al-Mujtahid wa Nihayat alMuqtasid. Translated edition by Imran Ahsan Khan Nyazee, Vol. 2, pp: 175-176. 
by other schools which do not require qabd prior to resell in the case of immovable objects like land.

Salam contract is one of the two notable exceptions that allow sale of nonexistent objects, however, many conditions must be fulfilled to meet the legality of this sale, the most important of which is payment of price at the time of contracting $^{(12)}$. Ibn Taymiyah and his student Ibn al-Qayyim did not consider salam as an exception to the general rule which rules the illegality of selling things not owned by the seller as understood from the texts. Rather, they adopted a different approach to the same texts by taking them to suggest forbidding selling things the seller of which is most probably not able to deliver. According to them, what was narrated in the Hadith is the prohibition of sales with excessive risk and uncertainty (gharar), where the object may be undeliverable, whether it exists or not (e.g. a runaway horse or camel). Thus the wisdom in the prohibition is neither existence nor lack thereof ${ }^{(13)}$.

Unlike the majority, which confined the meaning of qabd to holding and retention (habs) and evacuation (takhliyah), Ibn Taymiyah stated that neither the Arabic language nor the Shari'ah has given a specific meaning to qabd. Takhliyah varies from object to object and the manner in which it occurs is not always the same. The precise meaning of qabd is, therefore, is to be determined by reference to prevailing custom.

Hence, to Ibn Taymiyah and Ibn al-Qayyim, the meaning of such texts is "Do not sell things you are not able to deliver" and not, "Do not sell things you don't own". And in that particular Hadith Hakim is forbidden by the Prophet only to initiate transaction he may not be able to conclude, basically for two possible reasons: First, when he is asked to sell a specific and particular thing he does not own, so the owner of that particular thing may not agree to sell it. Second, when he is asked to sell things rarely found in the market. In both cases judge may not be able to deliver that thing, and for that reason he was not allowed to initiate such transaction ${ }^{(14)}$.

In other words they assert that the emphasis of the Hadith is on the seller's inability to deliver, which entails excessive risk and uncertainty (mukhatarah wa gharar). Hence, it is quite possible that the seller does not own it (qabd) at the point of sale as long as the delivery can be assured. For example, in the case of salam sale, the commodity must be capable of being specified exactly in

(12) al-Kasani, Bada' 'i al-Sana'i', 5/201: al-Dasuqi. Hashiyah, 3/195; al-Shirazi. al-Muhadhdhab, 1/262-263; Ibn Qudamah. al-Mughni, 6/385.

(13) Wahbah al-Zuhayli, al-Fiqh al-Islami wa Adillatuh, Vol. 5, pp: 3398-3340.

(14) Ibn al-Qayyim, 'I'lam al-Muwaqqi in, 2/19. 
quantity and quality, and concluded over fungible goods that are readily available in the locality ${ }^{(15)}$. This is to ensure that the risk and uncertainty with respect to future delivery can be minimized.

In general, selling what the seller does not own at the time of sale in a nonsalam contract is valid only according to Ibn Taymiyah and Ibn Qayyim, while it is invalid according to the majority of jurists. The majority scholars of Islamic jurisprudence assert the rationale ( illah) of prohibiting sale prior taking possession $(q a b d)$ was mainly due to the presence of gharar (excessive risk and uncertainty), which may lead to dispute amongst the transacting parties. This was because of the concern that the goods might not be delivered due to damage or other factors. Thus Islam prohibits any transactions involving bay ` ma 'dum since the delivery of the subject matter cannot be effected and this brings about the prohibited element of gharar.

In its $69^{\text {th }}$ meeting on 18 April 2006, the Shari ah Advisory Council (SAC) of Securities Commission of Malaysia, resolved that Regulated Short Selling (RSS) is in line with the Shariah. This fatwa is an extension of their earlier ruling on accepting securities borrowing and lending (SBL), which was held at its $13^{\text {th }}$ meeting on $19^{\text {th }}$ March 1998.

The essence of short selling transaction is the selling of shares not owned by the seller. As a result, as mentioned earlier the transactions may fall under the category of bay' ma'dum. As discussed in the preceding section, the 'illah of prohibiting sale without prior possession (qabd) as in the case of bai ma 'dum is mainly due to the presence of the prohibited element of gharar.

However, according to SAC's view, the issue of gharar can be overcome and hence eliminated in Regulated Short Selling (RSS) with the inclusion of Securities Borrowing and Lending (SBL) principles. In other words, the introduction of SBL can increase the probability that the shares sold will be delivered. When the probability of delivery is high, then the element of gharar will no longer be significant. Consequently, when an obstacle that hinders the recognition of a certain activity as Shari ah compliant is overcome, then that transaction or activity can be classified as Shari ah compliant.

(15) The legality of salam contract is mentioned in the Qur'an (2:282) and in an authentic Hadith where Ibn Abbas narrated that the Messenger of Allah (s.a.w.) came to Madinah, and found its inhabitants using salam contracts in fruits for one, two and three years. He (s.a.w.) said: "Whoever enters into a salam contract, let him specify a known volume or weight, and a known term of deferment”. al-Zuhayli (2003: 238). 
Their arguments are based on a well-known fiqh maxim: "When an issue that impedes (the permissibility) is removed, then the activity which was initially forbidden becomes permissible" (Securities Commission 2006). Therefore, short selling of items that are not owned by the seller takes place in the share market with the assurance by the exchange authority (Securities Commission) can remove the excessive risk and uncertainty (gharar) with respect to its delivery. Even if the short seller does not own the item when selling the shares, his ability to make delivery is nevertheless assured beyond doubt.

Referring back to our earlier example, Ahmad as the short seller is required to deal with a broker licensed by the Securities Commission. The broker (Ali as in our earlier example) is responsible to act on Ahmad's behalf by borrowing the shares (al-Barakah Petroleum Limited) from other traders, before subsequently selling it to the interested buyers. This inevitably secures delivery since the shares are traded by a licensed broker who acts on short seller's behalf. Furthermore the traded shares are always available in the market since it is monitored and regulated by Securities Commission. This further reinforces the probability of share delivery to the buyer and hence alleviates the excessive risk and uncertainty (gharar) associated with short selling transaction.

As for Ahmad, he can hold a short for as long as he wants. In other words, Ahmad does not have to purchase the borrowed stocks immediately after selling them to the respective buyers in the market. However, he can be forced to cover if the lender (Umar) wants back the stock he borrowed. Brokerages can't sell what they don't have, and so Ahmad will either have to come up with new shares to borrow or he is forced to cover. This is also known in finance terminology as 'called away'.

Therefore, referring back to the arguments given by different schools particularly on the issue of validity of sale based on qabd as well as the mechanism of Regulated Short Selling which closely monitored and regulated by the exchange authorities i.e. Securities Commission, we believe that short selling should be considered as legal sale and there is nothing wrong in doing it.

\section{Benefiting from Loan}

The third issue raised in the short selling is whether a person can benefit from loan contract, i.e. the stock owner who loans his shares to the short seller through the broker. Under the new Malaysian Short Selling rule, owners of stock will get a two per cent return on lending a minimum of 50,000 shares to a central lending pool, with Bursa Malaysia (Malaysian Stock Exchange) as the counter party. 
All jurists have ruled that any condition that a debtor should return additional amount over and above the loan is prohibited, whether the additional property belongs to the same type as the loan property or comes from a different type. It also does not matter whether the additional amount is excessive or minimum, as any such condition also negates the main purpose of the loan contract which is benevolence. Ibn Hazm says: Usury in loan may arise in both ribawi (items subject to riba al-bay') and non-ribawi properties. It is unlawful to give loan so as to be returned in lesser or higher quantities or in another type. Rather it must be returned in the same quality and quantity ${ }^{(16)}$.

Qurtubi says: there is a consensus among Muslim jurists based on the tradition from the Prophet (pbuh) that any stipulation for increase in a loan contract is usury even though if it is a fistful of forage as mentioned by Ibn Mas'ud or a single grain ${ }^{(17)}$.

The rationale behind forbidding the lender from stipulating any kind of increase is the fact that loan contract is meant to be a fully benevolent contract to help the borrower. Hence any gain realized by the lender at the expense of the borrower is contradictory to the essence of this contract, regardless of the benefit is financial or in-kind, substantial or small. Based on this fact, jurists established a well know maxim that reads "Any loan contract which benefits the lender amounts to riba" ${ }^{(18)}$.

With the exception of Malikis school, majority of jurists permit gifts or benefits derived from the loan contract if it was voluntarily and not stipulated as a condition or expected based on convention (urf). Their position is based on the Hadith narrated by Rafi mentioned earlier. Malikis on the other hand, render forbidden any gift given by the debtor to defer the debt and that cannot be explained by any other brotherly motives or obligations. In this case, the prohibition applies both to the giver and receiver. Thus the recipient of such gift must return them if they are intact, or pay their equivalent for fungibles and value for non-fungibles.

Malikis however allow unconditional rapayment of debt with increase if the debt resulted from a sale. Nevertheless if the debt resulted from a loan and if the increase was stipulated as a condition, was promised or was expected based on

(16) Ibn Hazm, al-Muhalla, 8:467, al-mas'alah (1479).

(17) al-Jami`li Ahkam al-Qur'an by al-Qurtubi:241/3.

(18) This fiqh maxims was orginally narrated as Hadith, but the credebiltiy of this Hadith with all its narrations was questioned and criticised. So, it is a weak hadith, but its meaning was endorsed by jurists. See al-Amir al-Sana ani. Subul al-Salam, 3/104-105, Hadith No 812; Ibn Nujaym. al-Ashbah wa'l-Naza'ir, p 316; al-Sharbini. Mughni al-Muhtaj,2/119. 
convention, then it is strictly forbidden. However the Malikis permit increases in quality in repayment of loans if they were not conditioned, promised, or expected. This opinion is based on the similar Hadith mentioned earlier about the Prophet (pbuh) borrowed a young camel and returned a more valuable older camel. But if the increase is in quantity rather than quality, the Malikis differed in opinion. In this case Malik in the Mudawwanah ruled that it is permitted only if the increase is very small, while 'Ibn Habib permitted such increases unconditionally $^{(19)}$.

In summary, it is not legal for the lender to stipulate any increase or profit in return of his loan. As regards the technical validity of the loan contract in which an increase has been stipulated, according to the Hanafis any condition by a creditor in a loan contract for any increase is void while the contract itself remains valid. According to the Shafies, both the condition and the loan contract are void ${ }^{(20)}$.

\section{Legality of Short Selling in Light of the above Discussion}

As already concluded, stocks can be lent to others based on the majority of jurists' norms related to determining what constitutes a valid subject matter of loan. As for the issue of the selling stocks before owning them, the opinion of Ibn Taymiah and Ibn Qaiyyem could be adopted here, as their argument is valid in principle, and its validity is self-evident nowadays when most of products have been standardized so they became easily obtainable. Moreover, the seller of stocks, through the stock broker, is mostly capable of delivering the stocks at any time, which meets Ibn Taymiyah and Ibn Qayyim's condition on selling things not owned by the seller at the time of sale.

However, even if we could find solutions to the problem of ownership of stocks by adopting Ibn Taymiyah and Ibn Qayyim's opinion, which we deemed valid, there is another perpetual problem which is difficult to overcome, namely the riba issue. It is known that in the application of short selling the lender, i.e. the stock owner, stipulates a gain in return for lending the stocks. However, as we have already concluded that any gain stipulated by the lender is deemed riba, therefore, the issue of the lender stipulating a return for lending the stocks becomes the fundamental factor in determining the legality of the whole transaction, this is regardless of the original ruling concerning stocks trading, as this is an issue in itself that necessitates a careful study and its legality cannot be taken for granted, especially in the light of the recent economic and social negative implications.

(19) al-Zuhayli, al-Fiqh al-Islami wa Adillatuh, Dar al-Fikr, (1984), Vol. 5, pp: 3793-3795.

(20) Ibn Abdin. Hashiyat (Radd al-Muhtar ala'l-Durr al-Mukhtar), 4/174; al-Nawawi. Rawdat alTalibin, 3/277. 


\section{Summary and Conclusion}

Modern commerce has witnessed a large number of new and unprecedented modes of trading which were not known in earlier times. One of these modes of trading which is commonly and widely used in the current capital market is short selling. It is believed that short selling contributes to the market by providing liquidity, efficiency, and acting as a voice of reason amongst the market trading participants. To recapitulate, short selling involves a transaction whereby an investor borrows shares, sells them and must eventually return the same shares (cover). Profit (or loss) is realized on the difference between the price when the shares are borrowed and compared to when they are returned. Hence, an investor will only make money when a shorted share falls in value.

This paper reviews the ruling passed by Shari ah Advisory Council of Securities Commission of Malaysia on short selling facility. In general their decisions are based on the basic norm and maxim of Shari' ah: "All transactions (except for ibadah) are permissible (ibahah) unless there is clear evidence from the sources (Qur'an and Sunnah) that prohibits them". Furthermore, a transaction is valid from the Shari ah perspectives when it does not violate a decisive principle. This means it must be clear of riba and it does not partake in excessive gharar. When these conditions are met, the transaction in question is valid and may be practiced.

With respect to short selling facility, this paper highlights and discusses three important fiqh issues evidenced in short selling transaction. First, on the issue of selling something which is not the seller's possession, we have highlighted the views of different schools. The main rationale ('illah) for such a prohibition is the incidence of gharar due to the probability of a seller not able to deliver. Since fulfillment of delivery, settlement of contracts and payment of financial obligations are always guaranteed, monitored and regulated by the exchange authority, the seller's ability to deliver is no longer a matter of concern in short selling transaction. Exchange authority may also provide mechanism for settlements of disputes among trading members, and hence realizing the objectives of Shari'ah (maqasid). Second, on the issue whether stocks can be a subject matter of a loan contract, the paper argues that stocks satisfy the homogeneity (mithli) properties in which all jurists, including the Hanafis, deem as an important criterion for objects to be eligible for lending. As long as the underlying subject matter that the stock represents is lawful (halal) from Shari ah purview, the stocks can be a subject matter of a loan contract.

Although we could find solutions to the problem of ownership of stocks in short-selling by adopting and applying some jurist opinion, the issue on benefiting from loan contract is still undefended. As thoroughly discussed, any 
gain stipulated by the lender is deemed riba. Hence, the issue of stock owner benefiting from the charges imposed on the lending stocks in short selling is apparently against the Shari'ah principles and hence a clear-cut riba.

Therefore the permissibility of regulated short selling ruled by Shari ah Supervisory Council of Malaysian Securities Commission requires reconsideration. This is because the Council only looks into the issue of bay' ma'dum while neglecting on the issue of riba. The riba element is evident in the short selling transaction whereby a stock owner gets a two per cent return on lending a minimum of 50,000 shares to a central lending pool as stipulated in the new rule of short selling in Malaysia.

\section{References}

Abu Dawud, (n.d.) Sunan. al-Maktabah al-'Asriyah, Beirut.

al-Amir, al-Sana ani (1998) Subul al-Salam, Dar al-Kitab al-'Arabi, Beirut, (Ed.) 11.

Bursa Malaysia (2006) "The Rules of Bursa Malaysia Securities Berhad". Bursa Malaysia Securities Berhad. Available:

http://www.klse.com.my/website/bm/rules_and_regulations/bursa_rules/downloads/bm_b rchapter7.pdf, accessed on 5 October 2006.

al-Dardeer (n.d.) al-Sharh Al-Kabir, Published with Hashiyat al-Dasuqi.

al-Dasuqi (n.d.) Hashiyah, Dar Ihya' al-Kutub al-Arabiyah.

El-Gamal, M.A. (2006) Islamic Finance: Law, Economics and Practice, Cambridge University Press, New York.

Fabozzi, F.J., Jones, F.J. and Robert Johnson, J. (2002) "Common Stock", In: F.J. Fabozzi (ed.), The Handbook of Financial Instruments, John Wiley \& Son, New York.

Fabozzi, F.J. and Modigliani, F. (2003) Captal Market: Institutions and Intruments, Prentice Hall, New Jersey.

Ibn Abdin (1987) Hashiyat (Radd al-Muhtar ala al-Durr al-Mukhtar), Dar Ihiya' al-Turath alArabi, Beirut.

Ibn Hazm (n.d.) al-Muhalla, Beirut, Dar al-Afaqal al-Jadidah.

Ibn al-Qayyim (1973) 'I'lam al-Muwaqi 'in, Dar al-Jil, Beirut.

Ibn Qudamah (1404 A.H.) al-Mughni, Dar al-Fikr, Beirut.

Ibn Nujaym (1983) al-Ashbah wa'l-Naza'ir, Dar al-Fikr, Beirut.

Ibn Majah (n.d.) Sunan, Dar al-Kutub al-'Imiyah, Beirut.

Imam Malik ibn Anas (1989) al-Muwatta of Imam Malik ibn Anas: The First Formulation of Islamic Law, Translated by A. A. Bewley, Kegan Paul International, London, New York.

Investopedia (2002) "Short Selling: What is Short Selling?" Available, accessed on 4 October 2006.

Investopedia (2002) "Speculation", Available, accessed on 4 October 2006.

al-Kasani (1982) Bada' al-Sanai, Dar al-Kitab al-Arabi, Beirut.

Muslim (n.d.) Sahih, Dar Ehia' al-Turath al-'Arabi, Beirut.

al- Nasa'i (1991) Sunan, Dar al-Kutub al-'Ilmiyyah, Beirut, first edition.

al-Nawawi (1992) Rawdhat al-Talibeen, Dar al-Kutub al-'Ilmiyyah, Beirut.

al-Qarafi (1994) Dhakhearh, Dar al-Gharb al-Islami, Beirut.

Zuhayli, Wahbah (1984) al-Figh al-Islami wa Adillatuhu, Dar al-Fikr, Damascus. 


\title{
قضايا فقهية فيما يتعلق "بالبيع القصير" كما هو مطبق في سوق المال الإسلامي بماليزيا
}

\author{
أشرف وجدي دسوقي \\ وعبدالعظيم أبوزيد \\ قسم الاقتصاد - كلية الاقتصاد و العلوم الإدارية \\ الجامعة الإسلامبية العالمية بماليزيا
}

المستخلص. يمثل وجود أسواق المال الإسلامية التأكيد على المبادئ

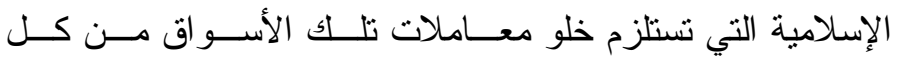

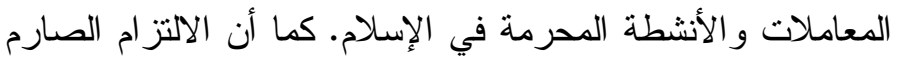

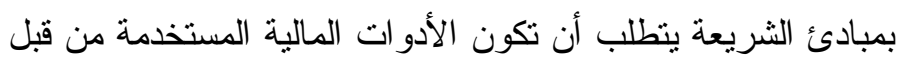
الأطر اف المتعاملة في أسواق المال "إسلامية".

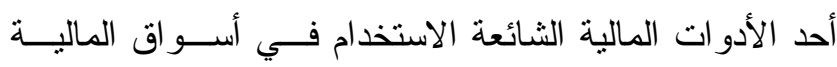

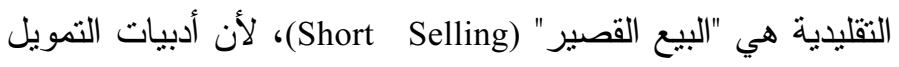

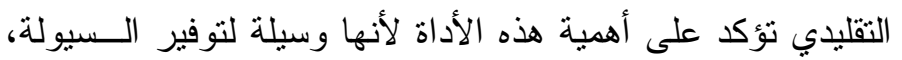

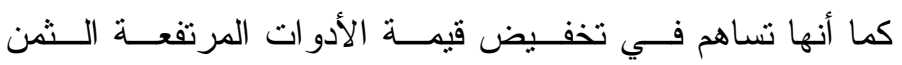
(Overpriced Stocks)

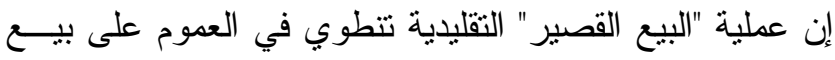

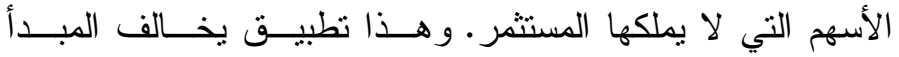

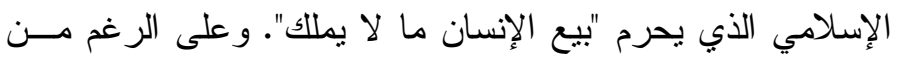

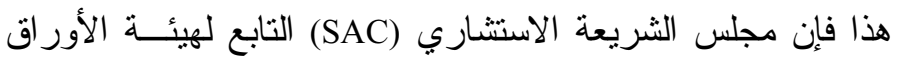

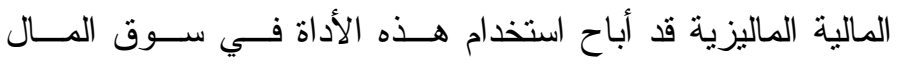
الإسلامي الماليزي مؤخرًا.

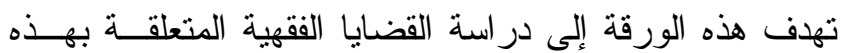

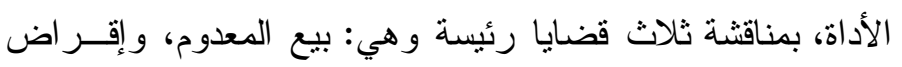

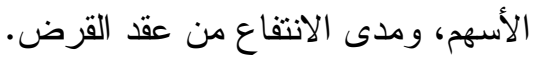

